\title{
The Zero Waste Catfish Product Innovation as an Empowerment Strategy Accompanied by Bunda KoJa Community Around Operational Area of PT Pertamina (Persero) Integrated Terminal Jakarta
}

\author{
Andri Akbar*, Ryan Hendra, Anita Ervina, Rida Aini Rahmawati \\ PT. Pertamina (Persero) Integrated Terminal Jakarta. Jl. Yos Sudarso, Jl. Yos Sudarso, Jembatan 1 \\ Plumpang, Jakarta Utara, North Jakarta/Jakarta Province, 14230, Indonesia
}

*Corresponding author:

E-mail: andriebar@gmail.com

\begin{abstract}
Rawa Badak Selatan is one of some villages in Koja Subdistrict, North Jakarta that dominated by toddler parents with a lack of knowledge and economic prosperity about food nutrition. Corporate Social Responsibility (CSR) of PT. Pertamina Integrated Terminal Jakarta is carrying the SULE program as a strategy to empower toddlers mother by innovating catfish products, this program aims to increase productivity and improve the nutrition of toddlers. The data collecting method is descriptive and the implementation program was by the participatory method. The SULE programs include learning about catfish product innovation, management of catfish food production, and product marketing. The food product development also conducts the zerowaste production that provides more benefits, reduce waste handling activities, increasing productivity, overcome environment pollutant, and increase income and efficiency. Catfish product innovations from the catfish fillet are nuggets, shredded meat, and sticks. Catfish bones are processed into bone chips, tempeh chips, and fishbone biscuits. The SULE program had a positive impact because toddler mothers with bunda koja community could have additional income from catfish production and marketing. In the future, innovations of new catfish processed products will be developed into great sociopreneur that improve the economy of more other toddler mothers.
\end{abstract}

Keywords: Catfish, toddler, food diversification

\section{Introduction}

Reduction and prevention of malnutrition are very important and need to be continuously developed (Scherbaum \& Srour, 2016). The case of malnutrition is often related to the socio-economic conditions of the people who reflect on the lack of knowledge in healthy and nutritious food consumption (Poel et al., 2007). The lack of parental income and lack of knowledge about food nutrition could be the causes of poor toddler parenting. The low parental income can cause them to be unable to provide nutritious food components for their children. Rawa Badak Selatan is one of some villages in Koja Sub-district, North Jakarta, which has the second-largest group of toddlers with a total of 5.304 (Tan, 2020).

The health research center (Riskesdas) data (2018) of DKI Jakarta province shows the proportion of malnutrition and malnutrition status was $15.6 \%$. Dr. Lisbet as the head of the Koja District Health Center, explain that Rawa Badak Selatan is one of the villages dominated by toddler's nutritional status that needs to be improved. Therefore, income and knowledge of toddlers' parents need to be improved, they might change the awareness of toddler food intake by the consumption of fish.

\section{How to cite:}

Akbar, A., Hendra, R., Ervina, A., \& Rahmawati, A. (2020). The zero waste cafish product innovation as an empowerment strategy accompanied by Bunda Koja community around operational area of PT Pertamina (Persero) integrated terminal Jakarta. ${ }^{\text {st }}$ International Conference Eco-Innovation in Science, Engineering, and Technology. NST Proceedings. pages 1-7. doi:10.11594/ nstp.2020.0501 
Fish have complete nutrition such as protein, vitamins, minerals, and fatty acids that very good for toddler health. The fish consumption rate in Indonesia was 41.11 kilogram per capita are still categorized low even in the Southeast Asian region (Djunaidah, 2017). Catfish is one of the food sources that can be processed and diversified into any kind of nutritious food, in addition to cheap and easy to find, catfish has high nutritional properties. Catfish (100 gram) contains $12.82 \%$ protein, $3.70 \%$ fat, $2.70 \%$ ash, $2.60 \%$ carbohydrate, and $5.59 \%$ calcium (Handayani \& Kartikawati 2015). The food product development nowadays also conduct zero waste production, because there is a huge fishbone is a by-product. According to Sulaeman (2008) explains the application of the concept of zero waste will provide more benefits and reduce waste handling activities. The benefits of applying the zero principle waste are increasing productivity, overcome the pollution environment, and increase income and efficiency. Catfish bone had a calcium content of $21 \%-25 \%$, the phosphorus content of $10 \%-11 \%$, and fat content of 7\% (Bechtel et al., 2018). Catfish diversified into various products including nuggets, shredded fried meat, and crispy sticks (Datta, 2015). Not only catfish that can be processed into the various products, catfish bone by-product which is high in calcium and other minerals can also be diversified into various products such as bone chips, bone tempeh chips, and biscuits.

The SULE (Serba Unsur Lele) is a toddler mother empowerment program from the Corporate Social Responsibility (CSR) of PT. Pertamina (Persero) Integrated Terminal Jakarta accompany by the bunda koja community aimed to improve child nutrition and increase the income of mother toddlers. Bunda koja community and the mothers of the toddler was educated about food nutrition and diversification of catfish products, they learned about to create good manufacturing practices of catfish products, then how to market their catfish products. This program aims to increase the productivity of toddler mothers, and improve toddler nutrition.

\section{Research Method}

This research is a descriptive study of qualitative methods. A descriptive study explains the implementation of the mother's toddlers and bunda koja community empowerment with the Corporate Social Responsibility (CSR) PT. Pertamina (Persero) Integrated Terminal Jakarta. Information sources of this study include the CSR PT. Pertamina (Persero) Integrated Terminal Jakarta as the program implementation informant, the toddler mothers, and bunda koja community as the participant of the program.

\section{Results and Discussion}

The Community empowerment activities carried out by participatory methods, bunda koja community was placed as a subject in each activity, with accompanying from the CSR PT. Pertamina (Persero) Integrated Terminal Jakarta starts from training in the introduction for utilized catfish products, production, and product marketing. This activity was conducted from October 2018 until February 2020.

\section{Nutrition education and food product development training}

The training of toddler mothers and bunda koja community is educating about the nutritional properties of catfish, the catfish economic value, the importance of nutrient intake for a toddler, and catfish product diversification. The output of this activity is toddlers' mothers become aware of the importance of nutrition for toddlers and increase creativity in various products from nutritious catfish (Mahmudiono et al., 2016).

The training began with a demonstration of catfish preparations then catfish product development (Figure 1). The product made from catfish fillet is catfish nugget, shredded catfish meat, and crispy catfish sticks. The development of new value-added food ingredients from catfish bone are tempeh catfish bone chips, catfish bone biscuit, and catfish bone chips. 


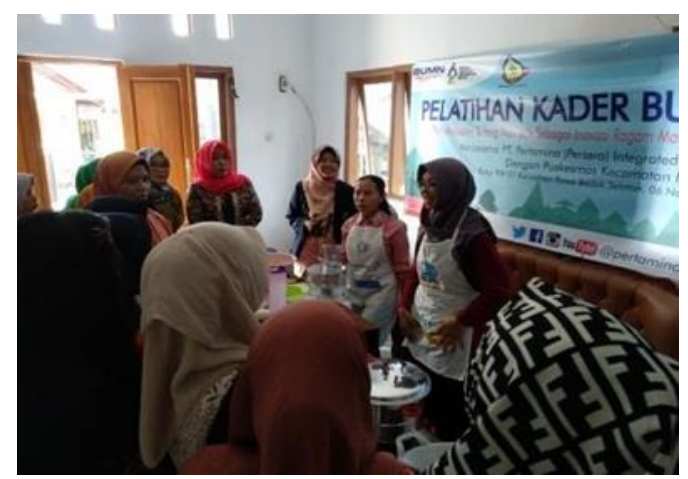

Figure 1. The training of catfish product development

The toddler mothers and bunda koja as the participant was curious about the catfish Product training. The enthusiasm of these mothers was good, through the discussion session many questions were raised related to catfish and its processed and business opportunities (Figure 2). The making of catfish nugget begins with fillet the fresh catfish off from bones, thorns, and skin. The fillet is then mixed with egg yolk, fine garlic, salt, and sugar using a blender. The mixture was then added with tapioca starch and stirred until well blended. The nugget dough then steamed for about 30 minutes. The steamed nugget then cut into the desired size and covered with egg white and then bread crumbs. The nuggets then are frozen before packaged in plastic pouches. Shredded catfish meat was made by sauteing the spices, lemongrass, galangal, bay leaves, orange leaves, brown sugar, and then coconut milk. Catfish meat that has been steamed and stirred then put into the spice mixture and kept cooked until dry.

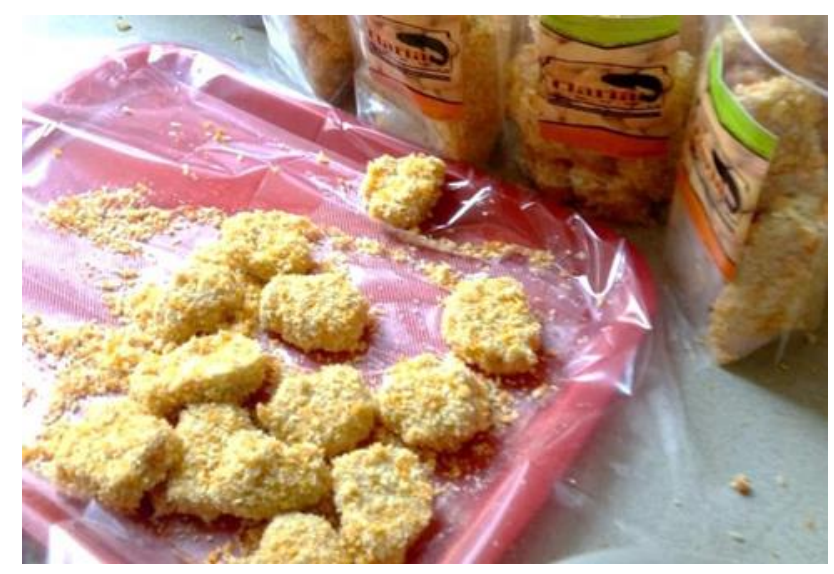

Figure 2 . The catfish nugget product made by bunda koja community

The making of catfish sticks begins with crushing the catfish fillet, then the eggs and oil put into wheat flour, tapioca starch, salt, sugar, and pepper. The mixture was stirred, then sliced scallions added, and then the dough kneaded until smooth. The dough then shaped into a stick using a pasta maker. The stick then fried in hot oil.

Fishbones in the production become untapped waste even though there are a high calcium and phosphorus content. The bone and head of catfish have $9.35 \%$ calcium content, higher than catfish fillet which is only $0.65 \%$. In addition to calcium, catfish bones contain phosphorus, magnesium, potassium, and sodium (Handayani \& Kartikawati 2015). These minerals are important micronutrients for toddler growth. Utilization of fish bones is initiated with the lacking amount of calcium consumption, the common source of calcium generally obtained from cow's milk that can not be reached by the underdeveloped economic society. Product fortification by the addition of 
fish bones with elements of calcium and phosphorus can be used as a source of micronutrients to improve nutritional quality.

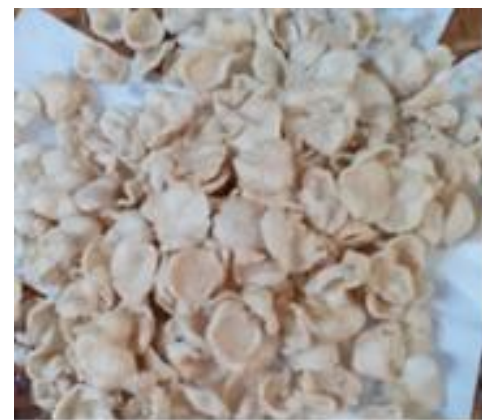

(a)

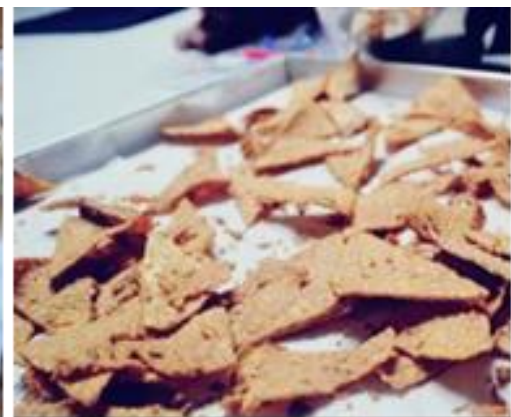

(b)

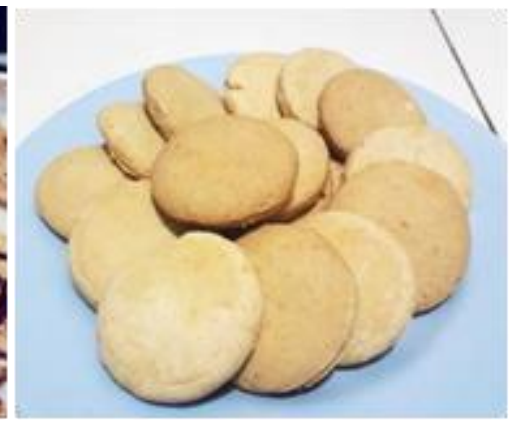

(c)

Figure 3. (a) catfish bone chips; (b) catfish bone tempeh chips; (c) catfish bone biscuits

Catfish bone steamed with a high pressure cooker for 2 hours. The boiling process softens the fishbone and is easily applied to various products. The making of biscuits begins by mixing flour, sugar, sweet potato, and catfish bones. The biscuits then baked in the oven for about 30 minutes. The making catfish bone chips begin by mixing catfish bone with tapioca starch, herbs, and spices. The dough then boiled and cut into a thin shape, after cutting the dough dried in the sun. The dried catfish bone chips are then fried in a hot oil pan, after that, the catfish bone chips are put into a chemical container.

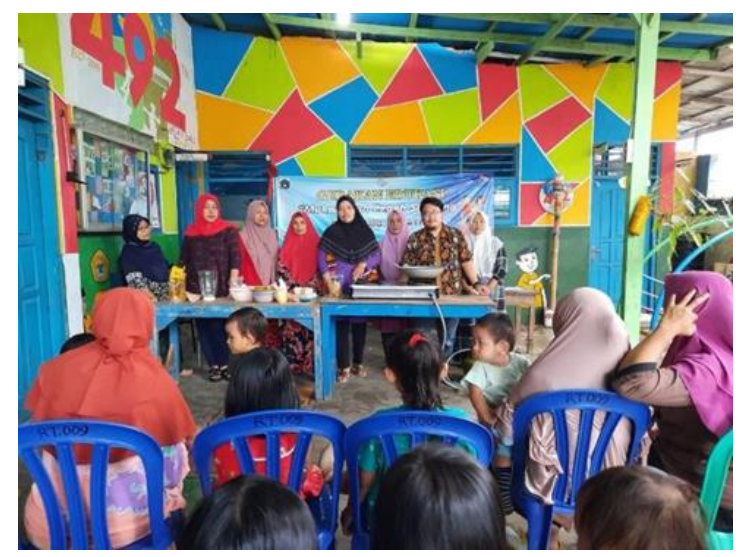

Figure 4. Bunda koja community train the toddler's mother

The training system is carried out using the training of trainer (tot) method, so bunda koja community can understand the materials through hands-on practice, they also could be the role act about the catfish product development and spread their knowledge to the wider environmental community. The training activity begins from the nutritional benefit of catfish consumption, the handling of raw material, and the manufacture of processed catfish products.

\section{The management assistance of catfish food production}

The next development of catfish products is to provide good production governance to obtain standardized product quality. Assistance activities are carried out by controlling and providing suggestions on every production activity and production management starting from making the Production Operational Standards (SOPs), the packaging procedure, and obtaining a product license such as perizinan produk industri rumah tangga (PIRT). Production of catfish development is carried out by the bunda koja community with toddler mothers beginning with the preparation 
of production SOPs, the preparation of good sanitation and hygiene standards. Catfish processing is highly perishable, the utilized any kind of catfish product must be very concerned about cold chain production so each product until a distribution is always kept frozen. Sanitation and hygiene are carried out by always washing hands with soap before and after production activities, every person must be using masks and gloves to prevent contamination. Equipment and production facilities always clean up after and before production.

The implementation of production activities also accompanied by financial management assistance, bunda koja community with toddler mothers could able to plan sustainable processing of catfish product. Assistance in the calculation of the production cost such as the calculation of variable costs, the cost of equipment, the cost of depreciation of equipment that adjusted to the production capacity. CSR PT. Pertamina (Persero) Integrated Terminal Jakarta assists with packaging and equipment needed during the production, distribution, and distribution.

Packaging and labels are supporting factors to products that can be liked, known, and commercialized properly. The products are also packed with pouched plastic to protect the product from contamination and increase product shelf life. Nuggets (ready to cook) are frozen, shredded products, bone tempe chips, and crackers are packed in zipplock plastic.

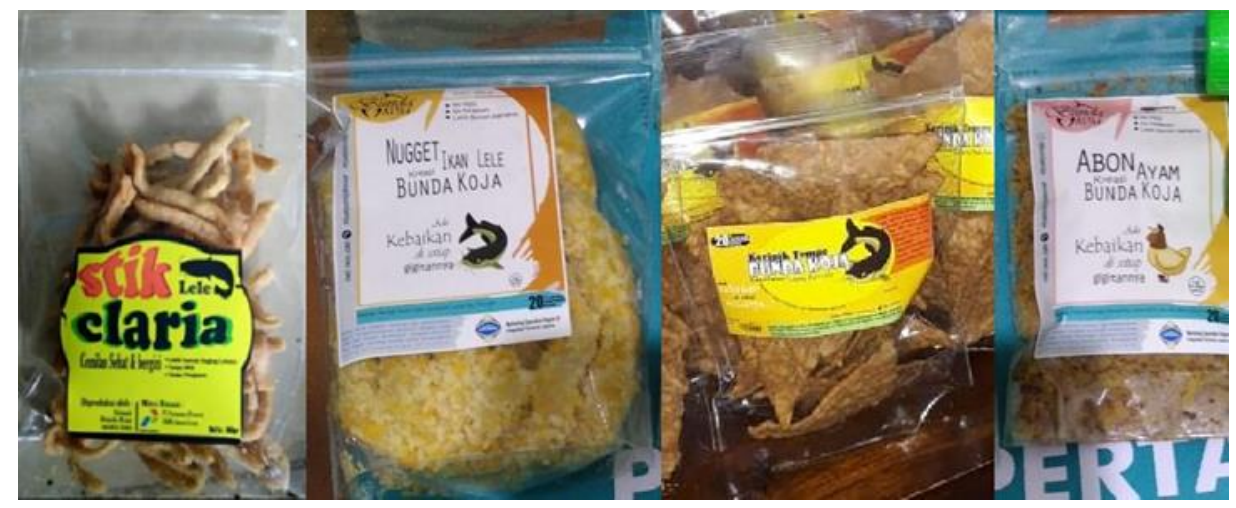

Figure 5. Packaging of catfish product innovation

Bunda Koja Comunity already produces and package products and ready to be an invention to a wide market. shredded catfish meat, nuggets, bone chips, and bone Tempe chips already produced and marketed that carried out through direct marketing and digital marketing so the products can be recognized by consumers on a larger scale.

\section{The Distribution and marketing of catfish food product}

Bunda koja community products are also introduced by the distribution to various outlets or stores, local media, social media, websites, community events, etc. Marketing development is carried out accompanied by the millennials generation from the Koja sub-district, marketing was carried out by elaborating the activities of the bunda koja community while the production activities, bunda koja community while helping the toddler mothers increase knowledge and providing additional income to help increase the nutritional intake of toddlers.

This SULE program supports the improvement of nutrition for malnourished children. Through the training of nutritious processed catfish products, mothers of toddlers can learn and understand the importance of nutritious food for toddlers and create food product innovations into business opportunities. A member of bunda koja community said "SULE can progress, succeed, thanks to Bunda Koja Community and her CSR companion. If there is no enthusiasm, this SULE could be failing. Now with SULE, I was being taught to make this product, we can also help toddlers who are malnourished. After all the program SULE can be more known in the market ... "(IN, 50 Years). 


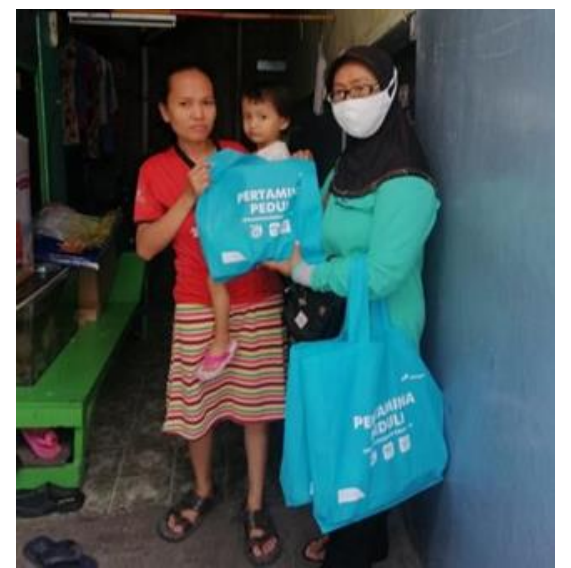

Figure 6. Awareness for a toddler mother to improve food toddlers nutrition

A small number of processed fish products made by mothers of toddlers are brought to be distributed to their toddlers as nutrition complementary, so indirectly that has an impact on improving parenting (Figure 6). This SULE program succeeded in having a positive impact on program recipients, especially toddlers mothers. According to the results of an interview with one of the program recipients, the existence of the SULE program can provide additional income for mothers of a toddler at Rawa Badak Selatan.

\section{Conclusion}

The SULE (Serba Unsur Lele) program has giving succeed impact on Rawa Badak Selatan toddlers, especially the additional income through the income of catfish products. Besides, the bunda koja community and mothers of toddlers received new knowledge about catfish product development. The role of PT. Pertamina, posyandu cadres, and Koja District Health Center were very influential in the development of the SULE program. CSR of PT. Pertamina has a role in providing stimulant funds as well as mentoring and monitoring the implementation of the SULE program. The SULE program to be a sustainable productive endeavor needs to be improved together, cooperation, and motivation of program members and the development of partnerships with local governments or stakeholders. Product innovations from catfish are potential to develop, not only nuggets, shredded meat, sticks, tempeh chips, and fishbone crackers, but also catfish bone crackers, brownies, catfish pempek, etc. can be developed into a new healthy food innovation. These innovative catfish products are very potential to develop into businesses and the potential to improve the economy of mothers of toddlers and surrounding communities.

\section{Acknowledgment}

The authors would like to thank all bunda koja community, mother toddlers, PT Pertamina (Persero) Terminal Jakarta, and all related parties that support the implementation of this research so that can be completed properly.

\section{References}

Bechtel, P. J., Watson, M. A., Lea, J. M., Bett-Garber, K. L. \& Bland, J. M. (2015). Properties of bone from catfish heads and frames. Food Science and Nutrition, 7(4), 1396-1405.

Datta, S. (2015). Prospects of value added fish products \& it's future in Indian market. Research Gate, 2015. doi: $\underline{10.13140 / R G \cdot 2.1 .3911 .1525}$

Djunaidah, I. S. (2017). Tingkat konsumsi ikan di indonesia : ironi di negeri bahari. Jurnal Penyuluhan Perikanan dan Kelautan, 11(1), $12-24$ 
Handayani, D. I. W., Kartikawati, D.(2015). Stik lele alternatif diversifikasi olahan lele (Clarias sp.) tanpa limbah berkalsium tinggi. Jurnal Ilmiah, 4(1), 109-117.

Kementrian Kesehatan Republik Indonesia. (2013). Peraturan Menteri Kesehatan Republik Indonesia No. 75 Tahun 2013 Tentang Angka Kecukupan Gizi Yang Dianjurkan Bagi Bangsa Indonesia. Jakarta: Kementrian Kesehatan Republik Indonesia, 2013.

Mahmudiono, T., Nindya, T. S., Andrias, D. R., \& Megatsari, H. (2016). The effectiveness of nutrition education for overweight/obese mother with stunted children (NEO-MOM) in Indonesia: Study protocol for a randomized controlled trial. BMC Public Health, 16(1), 115-120. doi: 10.1186/s12889-016-3155-1

Poel, E. V-del., Hosseinpoor, A. R., Jehu-Appiah, C., Vega, J., Speybroek, N. (2007). Malnutrition and the disproportional burden on the poor: the cae of Ghana. Int J Equity Health, 6, 21. doi: 10.1186/1475-9276-6-21

Scherbaum, V., \& Srour, M. L. (2016). The role of breastfeeding in the prevention of childhood malnutrition. World review of nutrion and dietetics, 115, 82-97. doi: $\underline{10.1159 / 000442075}$

Sulaeman, D. (2008). Zero Waste [Prinsip Menciptakan Agro-industry Ramah Lingkungan]. Jakarta: Direktorat Pengolahan Hasil Pertanian.

Tan, AN. 2020. Strategi penguatan modal sosial dalam pelaksanaan program CSR-Serba Unsur Lele. Bogor: Institut Pertanian Bogor 